\title{
Twardość wtórna połączeń spawanych stali energetycznych
}

\author{
Secondary hardness of heat resistant steels \\ welded joints
}

\section{Streszczenie}

W pracy oceniono skłonność do twardości wtórnej napoin stali 7 CrMoVTiB-10 oraz spoin złączy różnorodnych ściany szczelnej kotła parowego wykonanej ze stali 10CrMo9-10 (płaskownik) i stali X10CrMoVNb9-1 (rura). Metodą elementów skończonych (MES) z wykorzystaniem oprogramowania Sysweld (ESI Group) określono obszary SWC, w których możliwy jest wzrost twardości związany z twardością wtórną. Dokonano weryfikacji stanu naprężeń w konstrukcji spawanej ściany szczelnej. Pozwoliło to na ustalenie czynników sprzyjających rozwojowi pęknięć poprzecznych w spoinach ścian szczelnych kotłów parowych.
Abstract

In this work tendency to secondary hardness of 7CrMoVTiB-10 steel welds and dissimilar steam boiler membrane wall 10CrMo9-10 (flat bar) with X10CrMoVNb9-1 (pipe) weld joints was assessed. Using Finite Element Method with SYSWELD (ESI Group) possible growth of hardness connected with secondary hardness in $\mathrm{HAZ}$ area zones were define. Tension state on welded construction of membrane wall was verified. Results allows to determine factors which are conducive to initiate transverse cracks in steam boiler membrane wall welds.

\section{Wstęp}

Podczas wygrzewania w temperaturach niższych od $A_{c 1}$ uprzednio zahartowanych lub przesyconych składnikami stopowymi oraz zanieczyszczeniami obszarów złącza spawanego stali zachodzą istotne przemiany struktury. Siłą napędową tych przemian jest różnica entalpii swobodnej między metastabilnym martenzytem i strukturami przesyconymi, a mieszaniną faz uzyskaną po ich wygrzaniu złożoną zwykle z ferrytu i węglików. Stosunkowo dobrze poznane są procesy odpuszczania martenzytu, gdzie w zależności od warunków odpuszczania, głównie temperatury, można wyróżnić podstawowe stadia tego procesu. Najogólniej należą do nich rozkład martenzytu połączony z wydzielaniem, a następnie koagulacją węglików oraz przemiana austenitu szczątkowego w fazę $\alpha$. W przypadku spawalnych stali węglowych i węglowo-manganowych zjawiskom tym

Dr hab. inż. Andrzej Gruszczyk, prof. Pol. Śl., dr inż. Tomasz Kik - Politechnika Śląska, Gliwice. towarzyszy monotoniczny spadek twardości i poprawa właściwości plastycznych połączeń spawanych. Odmiennie w warunkach wysokiego odpuszczania zachowują się stale zawierające pierwiastki węglikotwórcze takie jak chrom, molibden, wanad i wolfram. Składniki te dopiero w zakresie temperatury $500 \div 600^{\circ} \mathrm{C}$ osiągają wystarczająco duże szybkości dyfuzji i mogą tworzyć węgliki stopowe. Uważa się, że w pierwszej fazie zarodkowania niezależnego fazy węglikowe są koherentne lub częściowo koherentne z osnową i charakteryzują się dużą dyspersją, dlatego wydzielenia np. $\mathrm{Mo}_{2} \mathrm{C}$ lub VC powodują zwiększenie twardości i ograniczenie właściwości plastycznych odpuszczanych stali. Jest to tzw. efekt twardości wtórnej. Stwierdzono także, że niewielkie dodatki silnie węglikotwórczych pierwiastków, jak np. tytan i niob, powodują w stalach chromowo-molibdenowo-wanadowych wyraźne zwiększenie efektu twardości wtórnej [1].

Rozpad faz umacniających i związane z tym przejście składników stopowych do roztworu oraz przesycenie innymi niż węgiel składnikami stopowymi jest 
mniej poznanym zjawiskiem, które może wystąpić w wysokotemperaturowej części SWC i w spoinach złączy spawanych zarówno tradycyjnych, jak i nowo opracowanych stali energetycznych. Różnice składu chemicznego tradycyjnej stali T22 i nowych stali energetycznych o zbliżonej zawartości chromu polegają na wprowadzeniu do nowych stali mikrododatków boru, niobu i wanadu w przypadku stali T23 oraz boru, wanadu i tytanu w stali T24 (tabl. I). W obu stalach podwyższono czystość metalurgiczną, ograniczono zawartość węgla do $0,1 \%$ oraz ustalono dopuszczalne zawartości azotu. W tej sytuacji tradycyjne podejście do spawalności pozwoliło na uznanie stali T24 za stal dobrze spawalną. Praktyka tego nie potwierdziła. Stabilność faz umacniających, ich rozpad oraz zjawiska przesycenia roztworu stałego, starzenia, umocnienia wydzieleniowego, twardości wtórnej i kruchości odpuszczania powinny być istotnymi aspektami metalurgii spawania nowoczesnych stali - nie tylko energetycznych.

Ograniczenie spawalności stali energetycznych wynikające z niekontrolowanych procesów wydzieleniowych wiązano do tej pory głównie z pękaniem wyżarzeniowym (relaksacyjnym). Cytowane w literaturze wskaźniki określające skłonność do pękania relaksacyjnego opracowane zostały dla różnych gatunków stali, wyraźna jest jednak różnica podejścia do tego zjawiska $[1 \div 3]$

$$
\begin{aligned}
& \Delta G=\mathrm{Cr}+3,3 \mathrm{Mo}+8,1 \mathrm{~V}-2 \\
& \mathrm{R}_{\mathrm{S}}=0,12 \mathrm{Cu}+0,19 \mathrm{~S}+0,10 \mathrm{As}+\mathrm{P}+1,18 \mathrm{Sn}+1,49 \mathrm{Sb} \\
& \mathrm{P}_{\mathrm{SR}}=\mathrm{Cr}+\mathrm{Cu}+2 \mathrm{Mo}+10 \mathrm{~V}+7 \mathrm{Nb}+5 \mathrm{Ti}-2
\end{aligned}
$$

Wskaźnik $\Delta G$ uwzględnia jedynie zawartość chromu, molibdenu i wanadu, czyli składników stopowych sprzyjających klasycznej twardości wtórnej stali. Wskaźnik $\mathrm{R}_{\mathrm{S}}$ uwzględnia składniki, które występują w stalach w ilościach śladowych i wpływają na odwracalną kruchość odpuszczania. Nowsze poglądy na temat pękania wyżarzeniowego ponownie podkreślają rolę struktur przesyconych i pierwiastków wywołujących efekt twardości wtórnej [2]. Znalazło to również wyraz we wskaźniku pękania $\mathrm{P}_{\mathrm{SR}}$, gdzie obok chromu, molibdenu i wanadu ważną rolę odgrywają miedź, niob i tytan, składniki stopowe tworzące z ferrytem roztwory o ograniczonej rozpuszczalności.
Odwracalna kruchość odpuszczania stali i połączeń spawanych stali energetycznych pozostaje nadal pro-

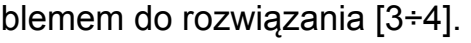

\section{Badania własne}

\section{Twardość wtórna napoin stali 7CrMoVTiB10-10}

Badaniom poddano napoiny wykonane na blasze o grubości $6 \mathrm{~mm}$ ze stali 7CrMoVTiB1010 o składzie chemicznym przedstawionym w tablicy II.

$\mathrm{Na}$ blachach wykonano napoiny łukiem krytym (SAW) z zastosowaniem topnika Böhler UV 305 oraz spoiwa o składzie chemicznym przedstawionym w tablicy III. Napawanie prowadzono bez podgrzania wstępnego. Regulowano energię liniową napawania w zakresie $4 \div 16 \mathrm{~kJ} / \mathrm{cm}$. Po napawaniu próbki poddano odpuszczaniu w temperaturze $100 \div 700^{\circ} \mathrm{C}$ co $100^{\circ} \mathrm{C}$ oraz w temperaturze $750^{\circ} \mathrm{C}$. Wyniki średnie z pięciu pomiarów twardości HV1 na przekroju poprzecznym napoin bezpośrednio po napawaniu oraz po obróbce cieplnej przedstawiono na rysunku 1.

Następnie metodą elementów skończonych (MES) z wykorzystaniem oprogramowania Sysweld firmy ESI Group określono pole temperatury podczas wykonywania badanych napoin z energiami liniowymi 4, 8, 12 i 16 kJ/cm. Wyznaczono odległość od osi

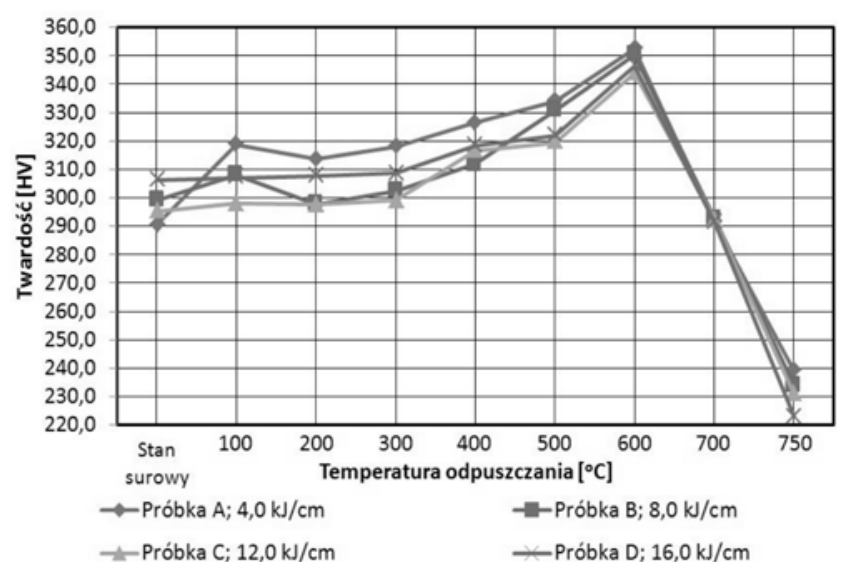

Rys. 1. Wpływ temperatury odpuszczania na twardość napoin 7CrMoV wykonanych łukiem krytym

Fig. 1. Influence of tempering temperature on $7 \mathrm{CrMoV}$ SAW welds hardness

\begin{tabular}{|c|c|c|c|c|c|c|c|c|c|c|c|c|c|c|}
\hline \multirow{2}{*}{\multicolumn{2}{|c|}{$\begin{array}{l}\text { Gatunek } \\
\text { stali }\end{array}$}} & \multicolumn{13}{|c|}{ Zawartość składników stopowych, \% wag. } \\
\hline & & $\mathrm{C}$ & $\mathrm{Si}$ & $\mathrm{Mn}$ & $\mathrm{Cr}$ & Mo & W & $\mathrm{Ti}$ & V & $\mathrm{Nb}$ & B & $\mathrm{N}$ & Co & Inne \\
\hline \multirow{3}{*}{$2 \mathrm{Cr}$} & T22(2,25-1) & $\begin{array}{l}\max \\
0,15\end{array}$ & $\begin{array}{c}\max \\
0,5\end{array}$ & $\begin{array}{l}0,3 \\
0,6\end{array}$ & $\begin{array}{l}1,9 \\
2,6\end{array}$ & $\begin{array}{l}0,87 \\
1,13\end{array}$ & - & - & - & - & - & - & - & $\begin{array}{c}\mathrm{Cu} \\
\max 0,3\end{array}$ \\
\hline & $\begin{array}{c}\text { T23, } \\
\text { HCM2S }\end{array}$ & $\begin{array}{l}0,04 \\
0,10\end{array}$ & $\begin{array}{c}\max \\
0,5\end{array}$ & $\begin{array}{l}0,1 \\
0,6\end{array}$ & $\begin{array}{l}1,9 \\
2,6\end{array}$ & $\begin{array}{c}0,05 \\
0,3\end{array}$ & $\begin{array}{l}1,45 \\
1,75\end{array}$ & - & $\begin{array}{l}0,20 \\
0,30\end{array}$ & $\begin{array}{l}0,02 \\
0,08\end{array}$ & $\begin{array}{l}0,0005 \\
0,0060\end{array}$ & $\begin{array}{l}\max \\
0,03\end{array}$ & - & - \\
\hline & T24, 7CrMo & $\begin{array}{l}0,05 \\
0,10\end{array}$ & $\begin{array}{l}0,15 \\
0,45\end{array}$ & $\begin{array}{l}0,3 \\
0,7\end{array}$ & $\begin{array}{l}2,2 \\
2,6\end{array}$ & $\begin{array}{l}0,9 \\
1,1\end{array}$ & - & $\begin{array}{l}0,05 \\
0,10\end{array}$ & $\begin{array}{l}0,20 \\
0,30\end{array}$ & - & $\begin{array}{l}0,0015 \\
0,0070\end{array}$ & $\begin{array}{l}\max \\
0,012\end{array}$ & - & - \\
\hline
\end{tabular}

Tablica I. Nominalne składy chemiczne wybranych żaroodpornych stali ferrytycznych

Table I. Nominal chemical composition of chosen heat resistant ferritic steels 
Tablica II. Skład chemiczny stali 7CrMoVTiB10-10

Table II. Chemical composition of 7CrMoVTiB10-10 steel

\begin{tabular}{|c|c|c|c|c|c|c|c|c|c|c|c|c|}
\hline \multirow{2}{*}{$\begin{array}{c}\text { Gatunek } \\
\text { stali }\end{array}$} & \multicolumn{10}{|c|}{ Zawartość składników stopowych, \% wag. } \\
\cline { 2 - 13 } & $\mathrm{Ci}$ & $\mathrm{Mn}$ & $\mathrm{P}$ & $\mathrm{S}$ & $\mathrm{Cr}$ & $\mathrm{Mo}$ & $\mathrm{V}$ & $\mathrm{Ti}$ & $\mathrm{Al}$ & $\mathrm{N}$ & $\mathrm{B}$ \\
\hline 7CrMoV & 0,08 & 0,25 & 0,52 & 0,008 & 0,002 & 2,44 & 1,00 & 0,264 & 0,070 & 0,011 & 0,0085 & 0,0053 \\
\hline $\begin{array}{c}\text { Skład wg } \\
\text { ASTM A } \\
213\end{array}$ & $\begin{array}{c}0,05 \\
\div 0,10\end{array}$ & $\begin{array}{c}0,15 \\
\div 0,45\end{array}$ & $\begin{array}{c}0,30 \\
\div 0,70\end{array}$ & $\begin{array}{c}\max \\
0,02\end{array}$ & $\begin{array}{c}\max \\
0,01\end{array}$ & $\begin{array}{c}2,2 \\
\div 2,6\end{array}$ & $\begin{array}{c}0,90 \\
\div 1,10\end{array}$ & $\begin{array}{c}0,20 \\
\div 0,30\end{array}$ & $\begin{array}{c}0,05 \\
\div 0,10\end{array}$ & $\begin{array}{c}\max \\
0,02\end{array}$ & $\begin{array}{c}\max \\
0,012\end{array}$ & $\begin{array}{c}0,0015 \\
\div 0,007\end{array}$ \\
\hline
\end{tabular}

Tablica III. Skład chemiczny spoiwa użytego do spawania stali 7CrMoVTiB10-10

Table III. Chemical composition of filler material for 7CrMoVTiB10-10 steel welding

\begin{tabular}{|c|c|c|c|c|c|c|c|c|c|c|c|c|}
\hline \multirow{2}{*}{ Materiał dodatkowy } & \multicolumn{10}{|c|}{ Zawartość składników stopowych, \% wag. } \\
\cline { 2 - 17 } & $\mathrm{C}$ & $\mathrm{Si}$ & $\mathrm{Mn}$ & $\mathrm{P}$ & $\mathrm{S}$ & $\mathrm{Cr}$ & $\mathrm{Mo}$ & $\mathrm{V}$ & $\mathrm{Ti}$ & $\mathrm{Cu}$ & $\mathrm{Nb}$ & $\mathrm{B}$ \\
\hline $\begin{array}{c}\text { Drut elektrodowy } \\
\text { UNION S P24 }\end{array}$ & 0,10 & 0,19 & 0,57 & 0,005 & 0,003 & 2,52 & 0,93 & 0,219 & 0,002 & 0,01 & 0,053 & 0,0002 \\
\hline
\end{tabular}

Tablica IV. MES Zasięg izotermy $T=600^{\circ} \mathrm{C}$ wyznaczony metodą MES oraz cechy geometryczne napoin wykonanych łukiem krytym przy różnych energiach liniowych spawania

Table IV. FEM results $-600^{\circ} \mathrm{C}$ isotherm range and SAW deposits dimensions welded with different heat input

\begin{tabular}{|c|c|c|c|c|}
\hline Energia liniowa spawania, $\mathrm{kJ} / \mathrm{cm}$ & 4 & 8 & 12 & 16 \\
\hline Zasięg izotermy $\mathrm{T}=600^{\circ} \mathrm{C}, \mathrm{mm}$ & 5,6 & 7,0 & 8,4 & 9,8 \\
\hline Szerokość lica, $\mathrm{mm}$ & 7,26 & 10 & 12,26 & 13,59 \\
\hline Wysokość nadlewu, $\mathrm{mm}$ & 1,16 & 1,92 & 2,04 & 1,96 \\
\hline Głębokość wtopienia, $\mathrm{mm}$ & 2,11 & 2,78 & 3,21 & 3,52 \\
\hline
\end{tabular}

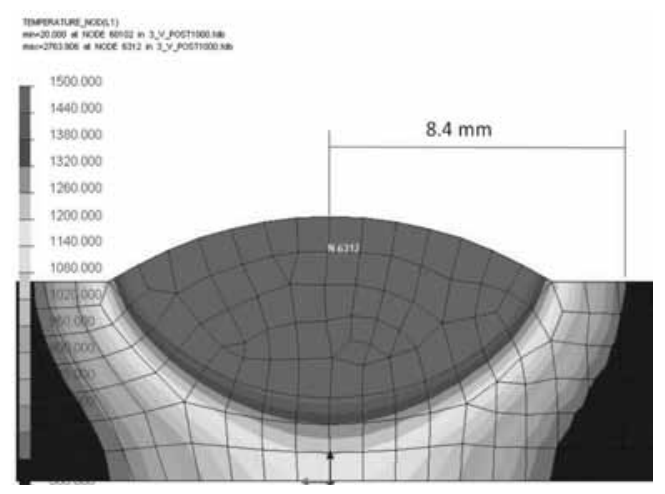

Rys. 2. Pole temperatury $\mathrm{z}$ zaznaczeniem zasięgu izotermy $\mathrm{T}=600^{\circ} \mathrm{C}, \mathrm{E}=12 \mathrm{~kJ} / \mathrm{cm}$

Fig. 2. Temperature fields with $600^{\circ} \mathrm{C}$ isotherm range selection, heat input $-12 \mathrm{~kJ} / \mathrm{cm}$

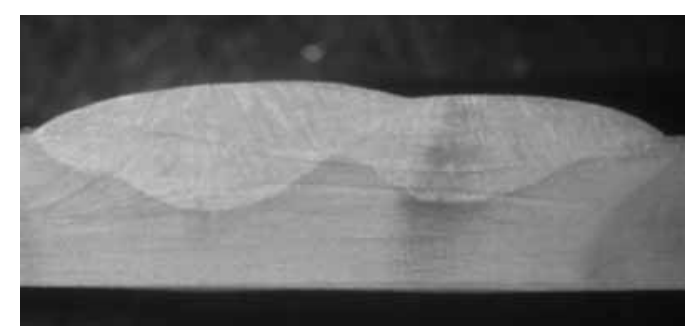

Rys. 3. Makrostruktura równolegle ułożonych napoin do badania wpływu złożonego cyklu cieplnego na skłonność do twardości wtórnej

Fig. 3. Macrostructure of parallel welded deposits for investigation of influence of complex thermal cycle on secondary hardness napoiny do izotermy $\mathrm{T}=600^{\circ} \mathrm{C}$ na powierzchni blachy (rys. 2, tabl. IV). Do kalibracji źródła ciepła w programie SYSWELD posłużyły zdjęcia makrostruktur oraz wymiary charakterystyczne napoin: szerokość lica, wysokość nadlewu i głębokość wtopienia, zawarte w tablicy IV.

Znając położenie izotermy $\mathrm{T}=600^{\circ} \mathrm{C}$, wykonanometodą SAW dwie równoległe napoiny $z$ energią liniową 4, 8, 12 i $16 \mathrm{~kJ} / \mathrm{cm}$, tak aby pierwsza napoina podlegała oddziaływaniu pola temperatury przy wykonywaniu drugiej napoiny, a izoterma $\mathrm{T}=600^{\circ} \mathrm{C}$ sięgała osi napoiny pierwszej. Przykładową makrostrukturę równolegle ułożonych napoin z energią liniową $12 \mathrm{~kJ} / \mathrm{cm}$ przedstawiono na rysunku 3.

Następnie przeprowadzono pomiary twardości HV1 na powierzchni przekroju poprzecznego napoin. Odległości między liniami i punktami pomiarowymi na liniach wynosiła $0,5 \mathrm{~mm}$. Wyraźny wzrost twardości zaobserwowano w napoinach pierwszych wykonanych z energią liniową spawania 8, 12 i 16 kJ/cm. Przykładowy rozkład twardości na przekroju poprzecznym napoin wykonanych z zastosowaniem energii liniowej spawania $12 \mathrm{~kJ} / \mathrm{cm}$ przedstawiono na rysunku 4.

\section{Twardość wtórna spoin złączy różnoimiennych ściany szczelnej}

Badaniom poddano złącza różnoimienne ściany szczelnej kotła parowego. Do wykonania ścian zastosowano rury ze stali wysokostopowej X10CrMoVNb9-1 (T91), płaskowniki ze stali 10CrMo9-10 (10H2M ) oraz 


\section{Napoina nr 2}

\section{Napoina nr 1}

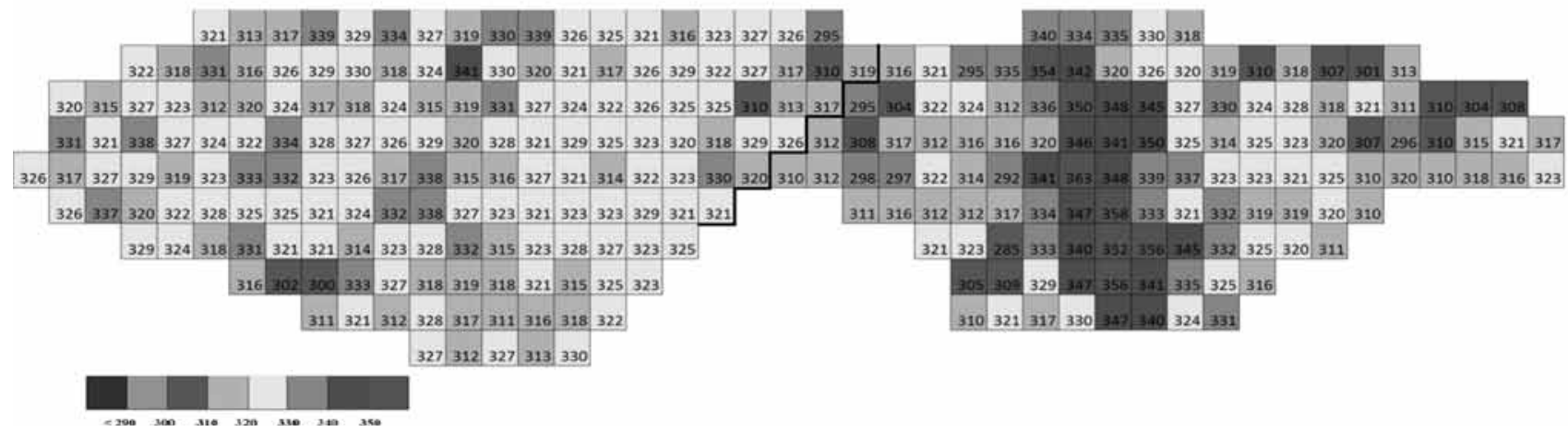

Rys. 4. Rozkład twardości na powierzchni napoin wykonanych łukiem krytym dla energii liniowej spawania $12 \mathrm{~kJ} / \mathrm{cm}$

Fig. 4. Hardness distribution on SAW deposits cross section, heat input $-12 \mathrm{~kJ} / \mathrm{cm}$

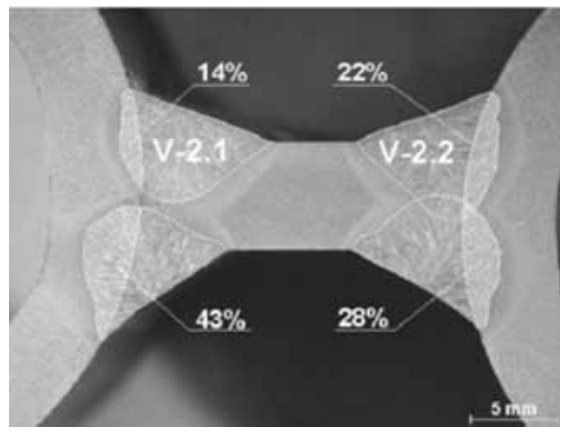

Rys. 5. Makrostruktura oraz udział materiału rodzimego rury w spoinach złącza różnoimiennego ściany szczelnej

Fig. 5. Macrostructure and dilution on membrane wall welds

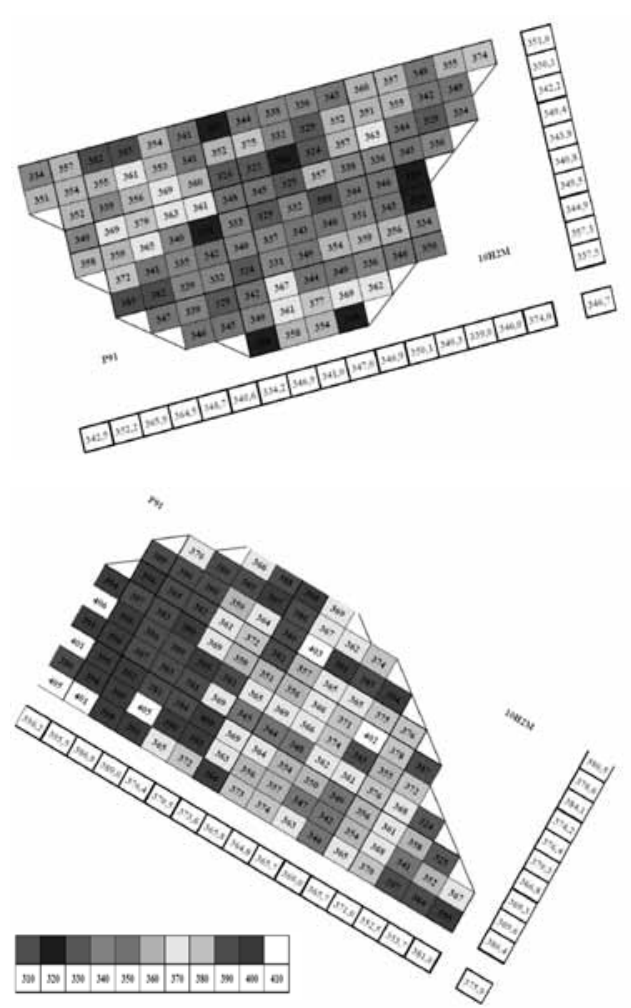

Rys. 6. Rozkład twardości na powierzchni spoin złącza ściany szczelnej, niżej spoina poddana ponownemu nagrzaniu (pierwsza), wyżej spoina wykonana później

Fig. 6. Hardness distribution on membrane wall cross section welds, below - weld reheated (first), upper - bead welded after spoiwo o składzie odpowiadającym stali 10CrMo9-10. Połączenia wykonano łukiem krytym z podgrzaniem wstępnym do temperatury $180^{\circ} \mathrm{C}$. Spawanie polegało na wykonaniu jednocześnie dwóch spoin łączących płaskownik i dwie rury. Następnie fragment ściany odwracano i wykonywano kolejne dwie spoiny. W ten sposób cykl cieplny spawania spoin wykonanych później oddziaływał na spoiny wykonane wcześniej. Złącza badano $w$ stanie nieobrobionym cieplnie. Typowe makrostruktury wymienionych połączeń z określeniem udziału materiału rury $w$ spoinach przedstawiono na rysunku 5.

Skłonność do twardości wtórnej spoin wykonanych jako drugie wybranego fragmentu ściany szczelnej określono, podobnie jak $\mathrm{w}$ przypadku napoin wykonanych na stali 7CrMoVTiB10-10 (rys. 1), przez pomiar twardości spoin bezpośrednio po spawaniu i po odpuszczaniu w zakresie temperatury od 100 do $750^{\circ} \mathrm{C}$. Stwierdzono zróżnicowaną skłonność spoin do twardości wtórnej. Maksymalne twardości spoin po odpuszczaniu $w$ temperaturze $600^{\circ} \mathrm{C}$ były od 20 do 50 HV1 wyższe od twardości zmierzonej bezpośrednio po spawaniu.

Oddziaływanie cyklu cieplnego spawania spoin drugich na właściwości spoin wykonanych wcześniej określono przez sporządzenie siatki twardości na całej powierzchni przekroju poprzecznego spoin. Odległości między liniami pomiarowymi oraz odstęp między punktami pomiarowymi na linii pomiarowej wynosił $0,5 \mathrm{~mm}$. Wyniki przedstawiono na rysunku 6.

\section{Modelowanie rozkładu temperatury i stanu naprężeń spawanej ściany szczelnej}

Celem analizy numerycznej była weryfikacja stanu naprężeń oraz rozkładu pól temperatury w konstrukcji spawanej ściany szczelnej. Analizę przeprowadzono przy użyciu metody elementów skończonych (MES) z wykorzystaniem specjalistycznego oprogramowania Sysweld firmy ESI Group.

Model geometryczny 3D wykorzystany w obliczeniach składał się z dwóch rur $\varnothing 63,5 \times 10,0 \mathrm{~mm}$ oraz płaskownika $8,0 \times 12,5 \mathrm{~mm}$ o długości $500 \mathrm{~mm}$. $\mathrm{Na}$ podstawie modelu geometrycznego stworzony 
został trójwymiarowy model obliczeniowy składający się z ok. 56510 elementów i 44108 węzłów. Parametry materiałowe, takie jak krzywa naprężenie-odkształcenie, współczynnik rozszerzalności cieplnej, ciepło właściwe, przewodność cieplna, moduł Younga, w przeprowadzonych symulacjach są zmienne w zależności od temperatury. Do symulacji numerycznych, zgodnie z procesem spawania, warunki brzegowe dobrano na podstawie sposobu mocowania elementów (rury i płaskownika) w czasie spawania. Jako źródło ciepła wykorzystano zdefiniowane w oprogramowaniu źródło Goldaka w kształcie podwójnej półelipsoidy. Zastosowano źródło uzupełnione o odpowiednie współczynniki korekcyjne bardzo dobrze odpowiada modelowanemu procesowi spawania łukiem krytym.

Przeprowadzona symulacja procesu spawania pozwoliła na określenie zakresu zmiany temperatury w czasie spawania zestawu pierwszych dwóch spoin, a następnie zasięgu izotermy $600^{\circ} \mathrm{C}$ w czasie spawania kolejnych spoin oraz stygnięcia spawanego elementu (rys. 7).

Analizie poddano również stan naprężeń konstrukcji w czasie spawania i po spawaniu. Wykazała ona szczególnie znaczący wzrost naprężeń w kierunku spawania (wzdłużnie do osi elementu) w obszarze płaskownika i spoin (rys. 8).

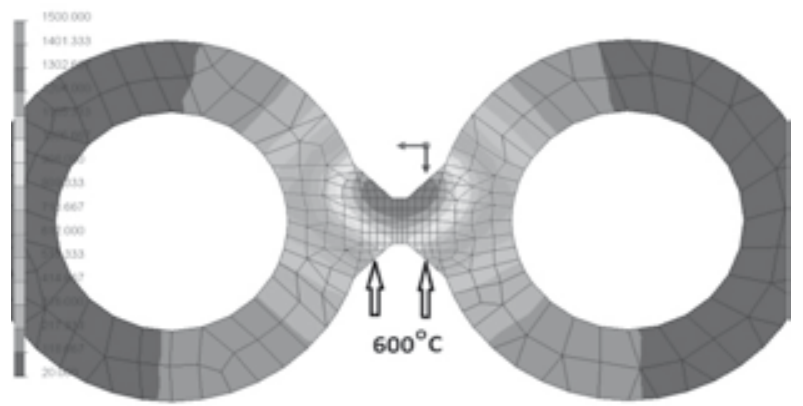

Rys. 7. Maksymalny zasięg izotermy $T=600^{\circ} \mathrm{C} w$ czasie stygnięcia spoin wykonanych jako drugie

Fig. 7. Maximum range of $600^{\circ} \mathrm{C}$ isotherm during welds cooling welded as second

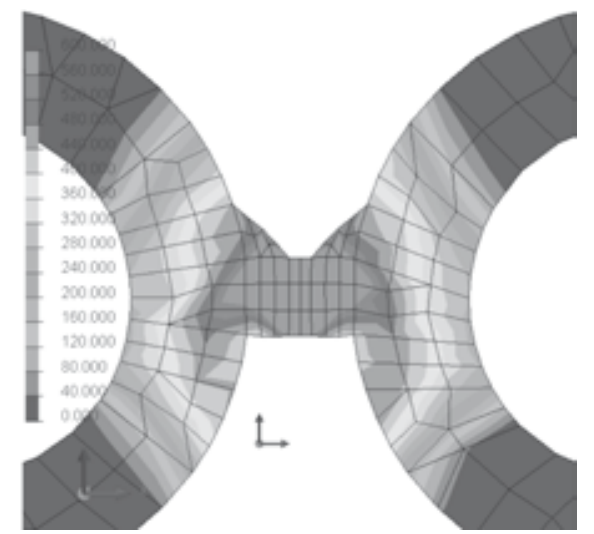

Rys. 8. Obszar maksymalnych naprężeń w kierunku osi spoiny po zakończeniu procesu spawania

Fig. 8. Area of maximal stresses along weld axis after welding

\section{Analiza wyników badań}

Próby napawania łukiem krytym stali 7CrMoVTiB10-10 nie wykazały istotnego wpływu energii liniowej spawania na twardość napoin $w$ stanie bezpośrednio po spawaniu. Wskazuje to, że procesy hartowania miały mniejszy wpływ na twardość tych napoin bezpośrednio po napawaniu. Wszystkie napoiny wykonane łukiem krytym wykazały istotną skłonność do twardości wtórnej. Maksimum twardości osiągnęły po odpuszczaniu w temperaturze $600^{\circ} \mathrm{C}$. Przyrost twardości badanych napoin kształtował się na poziomie ok. 50 HV1 (rys. 1). Efekt twardości wtórnej wystąpił również w wyniku ponownego nagrzania przy wykonywaniu dwóch równoległych napoin. Złożony cykl cieplny doprowadził do wzrostu twardości w obszarach napoin wykonanych z zastosowaniem energii liniowych 8, 12, i $16 \mathrm{~kJ} / \mathrm{cm}$, nagrzanych ponownie do temperatury ok. $600^{\circ} \mathrm{C}$. Szczególnie widoczny wzrost twardości zaobserwowano $w$ napoinie wykonanej $z$ energia liniową $12 \mathrm{~kJ} / \mathrm{cm}$ (rys. 4). Wywołany złożonym cyklem cieplnym proces odpuszczania doprowadził do podwyższenia twardości spoin i niewątpliwie pogorszył właściwości plastyczne w tym obszarze złącza. Procesy odpuszczania zachodzące $w$ warunkach spawania wielościegowego kojarzą się zwykle z obniżeniem twardości i poprawą właściwości plastycznych złącza.

W badanych napoinach doszło do wymieszania się niobu pochodzącego ze spoiwa $z$ tytanem pochodzącym ze stali T24 w proporcjach zależnych od parametrów spawania (tabl. II i III). Wg [5] proporcje między zawartością mikrododatków tworzących trwałe (Ti) i słabe $(\mathrm{Nb})$ fazy umacniające mają istotny wpływ na przebieg rozpuszczania i wydzielania się faz umacniających w czasie spawania.

Stale użyte do wytworzenia badanych ścian szczelnych kottów X10CrMoVNb9-1 (rura) i 10CrMo9-10 (płaskownik) różnią się istotnie składem chemicznym, właściwościami fizycznymi i eksploatacyjnymi. Stal $\mathrm{X} 10 \mathrm{CrMoVNb9-1}$ jest wysokostopową stalą martenzytyczną o zawartości chromu ok. 9\%, w której istotnymi dodatkami stopowymi są wanad (maks $0,25 \%$ ), niob (maks $0,1 \%)$ i azot $(0,03 \div 0,07 \%)$. Stal niskostopowa $10 \mathrm{CrMo9}-10$ o zawartości chromu ok. 2,25\% nie zawiera wanadu i niobu, a azot traktowany jest jako zanieczyszczenie. Wymieszanie w spoinie składników stopowych i zanieczyszczeń obu stali ze spoiwem o składzie stali 10CrMo9-10 powoduje, że spoiny uzyskały trudne do przewidzenia właściwości. Udział stali X10CrMoVNb9-1 w badanych spoinach zmieniał się w zakresie od 14 do $43 \%$ (rys. 5). Różnice stopnia wymieszania istotnie wpłynęły na proporcje między zawartością węgla, azotu oraz składników węglikoi azotkotwórczych. Badania twardości po odpuszczaniu wybranych spoin wykonanych jako drugie wykazały ich zróżnicowaną skłonność do twardości wtórnej. Maksymalne twardości spoin po odpuszczaniu w temperaturze $600^{\circ} \mathrm{C}$ przekraczały twardość po spawaniu 
o 20 $\div 50$ HV1. Pomiary twardości na całej powierzchni przekroju poprzecznego spoin wykazały, że w spoinie niepoddanej ponownemu nagrzaniu rozkład twardości był dość równomierny, a średnia twardość tej spoiny kształtowała się na poziomie 346,7 HV1 (rys. 6).

W spoinie pierwszej poddanej oddziaływaniu złożonego cyklu cieplnego twardość średnia była wyższa, ok. $376 \mathrm{HV1}$, co nie jest zaskoczeniem, bowiem spoiny różniły się stopniem wymieszania. Ciekawszy jest rozkład twardości na przekroju poprzecznym spoiny. Maksimum twardości wypadło w obszarze dość odległym od linii wtopienia spoiny drugiej w niskotemperaturowej części SWC. Spowodowane to zostało niekontrolowanymi procesami wydzieleniowymi zachodzącymi podczas ponownego nagrzania spoiny.

Modelowanie numeryczne rozkładu temperatury podczas spawania ściany szczelnej wykazało, że izoterma temperatury $600^{\circ} \mathrm{C}$ sięga do połowy przekroju spoiny wykonanej wcześniej (rys. 7). Wskazuje to, że wzrost twardości w spoinie pierwszej poddanej ponownie nagrzaniu wiązać należy $z$ twardością wtórną. Modelowanie MES stanu naprężeń podczas spawania ściany szczelnej wykazało jednoznacznie, że najwyższy poziom naprężeń rozciągających w kierunku osi spoiny występuje w obszarze płaskownika i spoin (rys. 8). Obniżenie właściwości plastycznych spoin w wyniku ich ponownego nagrzewania i wysoki poziom naprężeń rozciągających w kierunku osi spoiny, koncentrujących się w obszarze spoin i płaskownika, sprzyja rozwojowi pęknięć poprzecznych spoin ściany szczelnej, nie tylko w czasie spawania, ale również w czasie obróbki cieplnej i eksploatacji. W analizowanych przypadkach problemy związane $z$ twardością wtórną mogą być potęgowane w przypadku złączy różnorodnych stali X10CrMoVNb9-1 + 10CrMo9-10 mieszaniem się w spoinach składników stopowych, mikrododatków i zanieczyszczeń obu stali. W spoinach stali 7CrMoVTiB10-10 mieszają się $\mathrm{w}$ proporcjach zależnych od warunków spawania niob pochodzący ze spoiwa z tytanem pochodzącym ze stali 7CrMoVTiB10-10. Nasuwa się pytanie, jaki to ma wpływ na właściwości spoin?

Przydatnym narzędziem do analizy procesów zachodzących w czasie spawania stali energetycznych jest modelowanie MES $z$ wykorzystaniem oprogramowania Sysweld. Wyznaczone metodą MES pole temperatury w warunkach wykonywania różnych połączeń spawanych pozwala na wskazanie obszarów złącza, w których może dochodzić do procesów pogarszających właściwości złącza. Potwierdziły to pomiary, które wykazały wystąpienie efektu twardości wtórnej w spoinach i napoinach poddanych ponownemu nagrzaniu. W tych obszarach złączy spawanych stali energetycznych możliwe jest również obniżenie właściwości plastycznych związane z nieodwracalną kruchością odpuszczania.

\section{Wnioski}

- Wykonane łukiem krytym napoiny stali 7CrMoVTiB10-10 oraz spoiny połączeń spawanych różnorodnych stali 10CrMo9-10 + X10CrMoVNb9-1 wykazują skłonność do twardości wtórnej w czasie obróbki cieplnej i ponownego nagrzania podczas spawania.

- Wysoki poziom naprężeń rozciągających w kierunku osi spoiny oraz obniżenie właściwości plastycznych spoin w wyniku niekontrolowanych procesów wydzieleniowych sprzyjają rozwojowi pęknięć poprzecznych w spoinach ścian szczelnych kotłów parowych.

- Modelowanie MES z wykorzystaniem oprogramowania Sysweld jest przydatnym narzędziem do analizy procesów zachodzących w czasie spawania stali energetycznych.

\section{Literatura}

[1] Dobrzański L. A., Hajduczek E., Marciniak J., Nowosielski R.: Metaloznawstwo i obróbka cieplna materiałów narzędziowych. WNT 1990.

[2] Tasak E., Ziewiec A.: Spawalność materiałów konstrukcyjnych. Spawalność stali. Kraków 2009

[3] Newell W.F.: Challenges Meeting, Temper Embrittlement Criteria with Welding Consumables. IPEIA, 14-17 February 2007.

[4] Lalam S.H., Bhadesia D.H., Macka D.J.C.: Bruscato factor i temper embrittlement of welds. Science and Technology of Welding and Joining, 5/2000, Vol. 5.

[5] Wang G.R., Lau T.W., Weatherly G.C., North T. H.: Weld thermal cycles and precipitation effects in Ti-V-containing HSLA steels. Metallurgical Transactions A, 1989, Vol. 20A, 2093-2100. 